\title{
Tanya Fitzgerald and Elizabeth M. Smyth, eds. Women Educators, Leaders and Activists: Educational Lives and Networks 1900-1960
}

Houndmills, UK: Palgrave Macmillan, 2014. 214 pp.

\section{Rebecca Priegert Coulter}

University of Western Ontario

What happens when scholars, connected transnationally through networks of historical research on female educators, meet at a conference in the Antipodes? In an act of replication across time, they decide to draw on their own professional networks to plan and produce a book that turns our attention to the intellectual and personal networks of women who worked in education during the first half of the twentieth century. In Women Educators, Leaders and Activists: Educational Lives and Networks 1900-1960, readers will find seven chapters, plus a useful introduction by the editors and a thoughtful conclusion by Deirdre Raftery, that contribute to an understanding of how women in the past understood, navigated, and shaped their worlds - worlds that were created by British imperialism, colonization, capitalism, religion, and patriarchy.

Contributors to this volume provide insights into the efforts of women in six countries, England, Ireland, Canada, the United States, Australia, and New Zealand, and demonstrate how ideas and individuals flowed among these national states. For example, in a nuanced reading of her evidence, Tanya Fitzgerald traces the work of two English women, Winifred Boys-Smith and Helen Rawson, and the American, Ann Gilchrist, in establishing a foothold for women at the University of New Zealand through the Department (later Faculty) of Home Science, and professionalizing that field of study. At first blush, this created an apparently separate ghetto for women, but Fitzgerald argues that the female professors, working strategically within a gendered setting, used the site to establish home science as an academic and scientific field while offering young women courses in chemistry, biology, and nutrition and preparing them for graduate work in the sciences as well as for careers in public health, dietetics, social welfare, institutional management, and the like. Indeed, graduates 
of the program became part of the larger network enjoyed by their professors and were able to study and work not only in New Zealand but in the United States and England. Fitzgerald also suggests that the women's hostel set up to house the home science students provided a place where young women not only received practical training in household and institutional management but "learned to co-exist with one another, take up positions of authority and develop lifelong connections" (25).

Women working collectively and strategically to exercise agency and push against boundaries designed to exclude them is a strong theme in this book, well-illustrated by the work of women religious as Elizabeth Smyth shows for Canada and Judith Harford does for Ireland. In both countries the women religious in several different orders, in alliance with the graduates of their schools and the female laity, worked assiduously to promote women's education at the secondary and university levels. Smyth focuses primarily on the use of networks by Canadian women religious as they developed and promoted education for girls and women and supported one another in communities. She describes some of the concrete ways in which networks actually operated in local, national, and international arenas and within institutional church structures as well as within the congregations of women religious. Harford focuses her chapter on the efforts of Irish Catholic women, specifically the women religious in the Dominican, Loreto, and Ursuline orders and lay women such as Mary Hayden. One of the real strengths of this chapter is the way in which Harford skillfully provides the wider social and political context for women's struggles for higher education, includes discussion of the efforts of both Protestant and Roman Catholic women, and explains the specific challenges of the Catholic women's campaign.

This edited collection makes a conscious effort to be coherent. Many of the authors actively make connections between their chapters and those of others and this adds to the comparative nature of the work. The four chapters that provide biographies of individual female educators highlight core themes of the book - women networking, leading, and reforming in institutional settings and circumstances they had little part in creating. These biographies also illustrate the tensions and contradictions women confront as they seek to exercise power and control over their own lives.

Joyce Goodman and Zoe Milsom explore such tensions in the career of headmistress Reta Oldham who was born in Ireland but spent most of her career in England. Using spatial analysis, the authors examine Oldham's personal and professional identities and the ways in which she "enhanced transnational identities that were interrelated with gender and age" (97). Also drawing on ideas about space and place, Kay Whitehead similarly unpacks the life of Mary Gutteridge, an early childhood educator and founder of the Australian nursery school movement. Whitehead discusses what she calls Gutteridge's "transnational careering," her web of relationships, her professional networks, and her reputation for cosmopolitanism.

The life of Bessie (Wene) Te Wenerau Grace (Sister Eudora CSC) surely deserves a book of its own. Kay Morris Matthews with Jonathan Mane-Wheoki identify Wene Grace as the first Maori educational leader who networked internationally. Their writing about a life lived from New Zealand to England to Australia is rich and provocative, but the very complexity of Grace's name and the details of her life 
raise important questions about assimilation and identity. The daughter of a Maori mother and European father, she lived and was educated largely as a New Zealand European child while living in the home of her father's relatives. In 1912 she applied for and was granted status as a New Zealand European. Was this a pragmatic choice? How did Wene Grace self-identify? How did this shape her work as an educator? These are only some of the many questions this intriguing chapter raises.

The final biography is of Henrietta Rodman, a New York teacher and militant activist for women's rights. In it, Patricia Carter describes and analyses Rodman's work in the campaign for teachers' marriage and maternity rights, and situates it within the larger feminist agenda for economic independence and employment rights. Rodman's actions reveal a courageous woman who utilized a range of tactics and strategies to effect change. She paid a considerable personal price for her efforts but Carter concludes that the work of Rodman and other feminists in the early decades of the twentieth century accelerated change about married women and their right to work.

Fitzgerald and Smyth open their introduction to this edited collection with the quote from Virginia Woolf's Three Guineas about joining the procession of educated men. They suggest that women have taken up Woolf's challenge since educational qualifications and work as educators "offered women a way to join that procession" (1). But Woolf was more critical than that. For her, joining the procession was not enough and so she asked deeply political questions: "On what terms shall we join the procession? Above all, where is it leading us, the procession of educated men?" These questions demand consideration. 